\title{
Identifying and Quantifying Phakopsora pachyrhizi Spores in Rain
}

\author{
C. W. Barnes, L. J. Szabo, and V. C. Bowersox
}

First and second authors: Cereal Disease Laboratory, U.S. Department of Agriculture-Agricultural Research Service, and University of Minnesota, St. Paul, MN; and third author: Illinois State Water Survey-National Atmospheric Deposition Program, Champaign, IL. Accepted for publication 10 December 2008.

\begin{abstract}
Barnes, C. W., Szabo, L. J., and Bowersox, V. C. 2009. Identifying and quantifying Phakopsora pachyrhizi spores in rain. Phytopathology 99:328-338.

In summers of 2005 and 2006, rain was collected weekly at over 100 selected National Atmospheric Deposition Program/National Trends Network sites across the soybean-growing region of the central and eastern United States. Rain samples were screened for Phakopsora pachyrhizi (causal agent of soybean rust) DNA using a nested real-time polymerase chain reaction assay. Over this time frame, $P$. pachyrhizi

positive for $P$. pachyrhizi was found in both years. However, there was a greater than threefold increase in the number of samples testing positive for P. pachyrhizi in 2006 compared with 2005, with the most significant increase in August. There was also an increase in the average number of spores per sample in 2006 relative to 2005. Sequence analysis of a subset of positive samples was used to validate the assay results. From the sequence analysis, two reliable polymorphic regions were found, resulting in six distinct genotypes. One genotype was found in 56\% of the samples tested, whereas the other genotypes were found less frequently.
\end{abstract} spores were detected in every state in the study, but more frequently in states along the Gulf and Atlantic coasts and along the Ohio River Valley westward to Kansas. A bimodal temporal distribution of samples testing
Additional keywords: long-distance dispersal (LDD), Pest Information Platform for Extension and Education (PIPE).
Soybean rust (SBR) caused by Phakopsora pachyrhizi Syd. \& P. Syd. can be a devastating disease of soybean, with losses reported in Asia as high as $80 \%$ (4). For most of the twentieth century, however, SBR was generally restricted to Asia, until the disease began to rapidly spread in the 1990s. The disease was first reported in Hawaii in 1994 (12), Africa in 1996 (14), South America in 2001 (17), and the continental United States in 2004 (26). SBR is now a concern in all major soybean-growing regions of the world.

Conditions favorable for SBR development do occur in a typical growing season throughout most of the major U.S. soybean production area $(3,15)$ but not year-round $(20)$. Because no aecial host is known (3), overwintering, or survival between periods of host availability, is believed to be restricted to urediniospore survival, which is restricted by temperature, moisture, and available living host tissue $(15,20)$. Within the continental United States, those areas are largely confined to perennial weed legumes in the southern parts of states bordering the Gulf of Mexico $(15,19)$. Additional inocula sources could be from infected legume hosts in Mexico and islands of the Caribbean. Therefore, long-distance dispersal of airborne urediniospores would be necessary if SBR were to become a problem for the major soybean production area of the central United States.

Long-distance dispersal (LDD) of fungal spores that are ultimately deposited in rain showers has been observed in North

Corresponding author: C. Barnes; E-mail address: barn0107@umn.edu

* The $\boldsymbol{e}$-Xtra logo stands for "electronic extra" and indicates that the online version contains two tables showing data for each site in 2005 and 2006 and a figure showing DNA sequence alignment for the complete set of samples.

\section{doi:10.1094/PHYTO-99-4-0328}

This article is in the public domain and not copyrightable. It may be freely reprinted with customary crediting of the source. The American Phytopathological Society, 2009.
America $(23,25,28)$, in Europe $(9,10)$, and intercontinentally $(5,18,22)$. The role of rain-deposited urediniospores in establishing primary infection by Puccinia graminis and P. triticina on wheat in the northern wheat-growing areas of the United States has been shown (25). In comparing different types of spore traps, Roelfs et al. (23) recovered stem rust urediniospores in rain samples $\approx 10$ days before trapping them on $5-\mathrm{mm}$ rod impaction traps. In their study, detection of rust spores on impaction traps generally coincided with the local spread of spores within and between fields. Therefore, at least for ground-based detection systems, the use of rain traps to detect the initial arrival of spores prior to disease development is most useful.

Past studies of spore transport in rain have generally utilized only a small number of traps, making spread of primary inoculum into a broad geographic region difficult to detect. Therefore, to monitor dispersal of spores from a recently introduced pathogen, such as Phakopsora pachyrhizi where inocula sources are relatively unknown or not well established, deploying a greater number of traps at a larger scale would be ideal. The National Atmospheric Deposition Program/National Trends Network (NADP/ NTN; available online) provides a nationwide network of monitoring sites where precipitation is collected weekly. Established in 1978 with 22 sites, it currently exceeds 250 sites, spanning the continental United States, Alaska, Puerto Rico, and the Virgin Islands.

Information on $P$. pachyrhizi urediniospore transport into soybean-growing regions of the United States where the rust fungus does not normally overwinter would be useful to predict epidemics or to guide scouting efforts. The objectives of this study were (i) to develop an assay sensitive enough to detect one or more spores suitable for monitoring the initial deposition of inoculum and (ii) to assay precipitation collected at NADP/NTN stations located across the major soybean-growing regions of the continental United States to assess patterns of spore deposition during the soybean-growing season. 


\section{MATERIALS AND METHODS}

Laboratory precautions. One general concern in this study was the risk of contamination when using a nested real-time quantitative polymerase chain reaction (qPCR) method to detect DNA. Therefore, precautions were followed regarding the laboratory equipment and practice. Separate working rooms or areas were used for the preparation of positive controls, rain filter preparation, DNA extraction, and qPCR. A set of micropipettes was designated to be used solely to prepare the mastermix for the assays, and never came in contact with DNA. In filter preparation, disposable laboratory gloves and razor blades were changed between each filter. All assay reagents were aliquoted in a BioSafety cabinet (SterilGard; The Baker Company, Sanford, ME), frozen and used once, and discarded each day. The assay reagents aliquoted included primers, the TaqMan probe, purchased sterile water, Tris EDTA (TE), and Tris buffers. OmniMix (Packaged for TaKaRa Bio Inc. by Cepheid, Sunnyvale, CA), used as the mastermix, is in a bead form with one bead per tube. For each set of assay reactions, samples and the negative control were always prepared before the positive control.

Contamination, estimated by the number of negative controls with a positive threshold cycle $\left(\mathrm{C}_{\mathrm{T}}\right)$ value, occurred in $4 \%$ of the assays in 2005 and $6 \%$ of the assays in 2006. The frequency of contamination increased when the number of rain samples testing positive increased in both 2005 and 2006, and decreased when the frequency of positives samples fell (data not shown). When the negative control of an assay showed a positive result, all assay reagents were discarded, new aliquots were used, and the assay was rerun. If the negative control still showed a positive result, all samples in that assay were considered contaminated. Using new reagent aliquots worked to eliminate the false positive occasionally, reducing the number of samples being lost to contamination to 3\% in 2005 and roughly $4 \%$ in 2006.

Rain sample collection and sample preparation. Each week, precipitation from individual NADP/NTN sites was sent to the Illinois State Water Survey in Champaign, IL, and filtered according to a standard protocol with a minimum volume of $0.02 \mathrm{in}$. (7). Samples were filtered in total or for $1 \mathrm{~h}$ if filtration was slow. Filters were dried for $24 \mathrm{~h}$ in individual petri dishes. Once dried, petri dishes were sealed and sent overnight to the Cereal Disease Laboratory (CDL) in St. Paul, MN. Filters were assayed from rain collected at 121 and 110 selected NADP/NTN sites across the soybean-growing region of the central and eastern United States in 2005 and 2006, respectively (Fig. 1). Rain was assayed from weekly collections made between 10 May and 30 August in 2005 and from 9 May to 17 October 2006. At the CDL, rain filters were handled under sterile conditions in a biosafety cabinet. Filters were cut in half with a disposable razor blade, with one-half of the filter assayed for P. pachyrhizi and the other stored at $-80^{\circ} \mathrm{C}$. Each half filter to be assayed was fan-folded with a fresh pair of latex gloves and placed in a $2-\mathrm{ml}$ microcentrifuge tube. Filters were submersed in $10 \mathrm{mM}$ Tris- $\mathrm{HCl}$ buffer $(\mathrm{pH} 8.0)$, soaked in a $65^{\circ} \mathrm{C}$ water bath for $5 \mathrm{~min}$, and sonicated for $1 \mathrm{~min}$. Filters were inverted with sterile toothpicks and soaked and sonicated a second time as above. Filters were removed with a sterile toothpick, placed in a new 1.5 -ml microcentrifuge tube, and spun briefly to remove residual buffer. Samples were dried by centrifugation in a Speed Vac SC110 (Thermo Fisher Scientific, Inc., Waltham, MA) overnight. A separate 8.0- $\mu \mathrm{m}$ filter was placed over the air intake opening to prevent movement of spores into and out of the Speed Vac. The following morning, the dried samples were shaken with 10-15 1-mm glass beads in a Savant FastPrep shaker (FP120; Holbrook, NY) for $20 \mathrm{~s}$ at a speed setting of 4, spun down, and shaken a second time at the same setting. DNA was extracted using the OmniPrep Genomic DNA kit (GenoTech Inc., St. Louis) and using muscle glycogen as a DNA carrier. DNA was stored dry at $-20^{\circ} \mathrm{C}$ until assayed. To assay samples for $P$. pachyrhizi, samples were rehydrated overnight in $15 \mu \mathrm{l}$ of sterile water. Assays were performed immediately the following morning. TE $(2 \mu \mathrm{l})$ was added to the remaining sample after it was assayed and stored at $-80^{\circ} \mathrm{C}$.

Assay development. A primary goal of this study was to develop an assay to consistently detect a single spore of $P$. pachyrhizi in rain. Three assays were evaluated. The first assay was adapted from Barnes and Szabo (2) using the ITS1rustF10d forward primer with a reverse primer ITS1rustR3d. The reverse primer was modified from a similar primer (ITS1rustR3c) (2) to move a single nucleotide mismatch toward the $5^{\prime}$ end of the primer. A TaqMan probe was designed specifically for $P$. pachy-

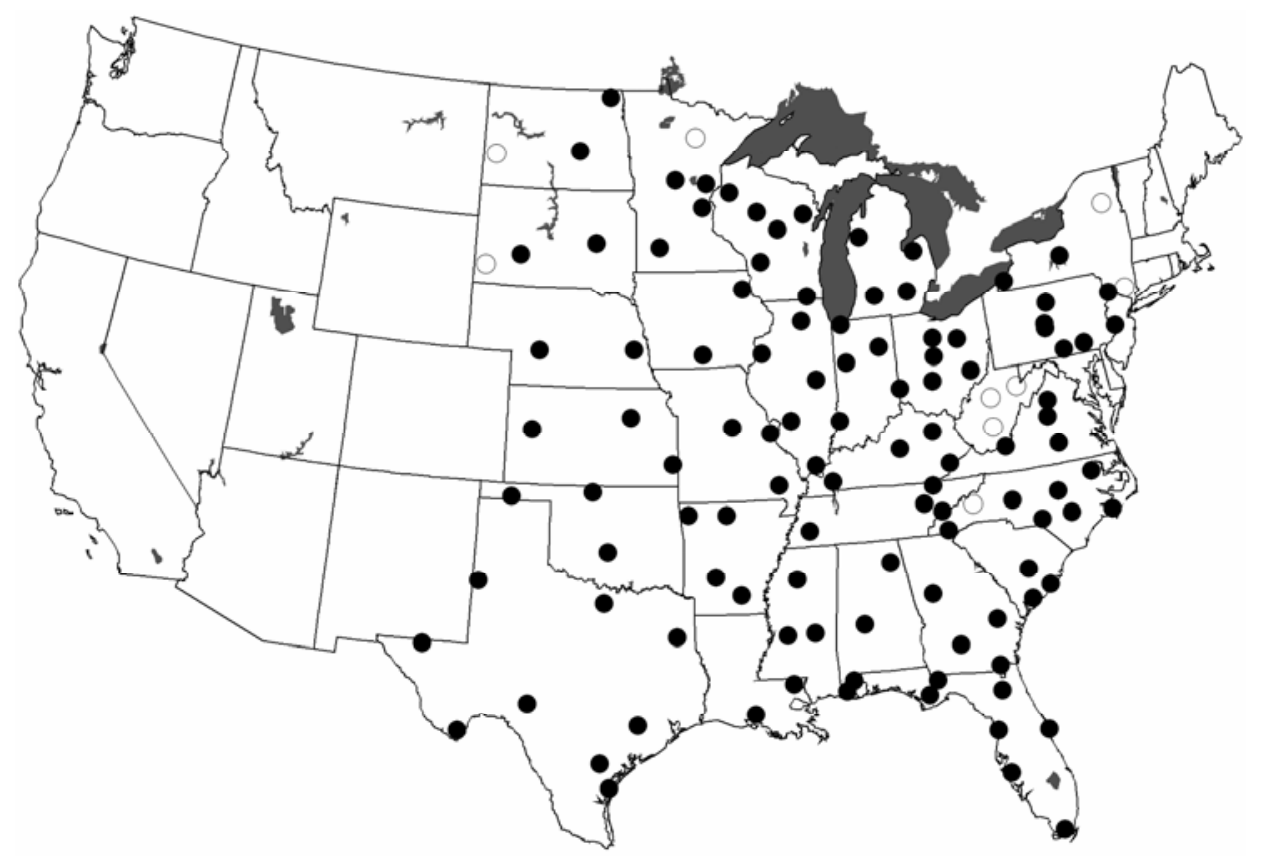

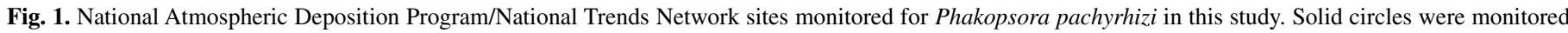

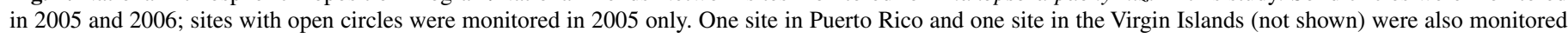
in 2005 only. 
rhizi in the internal transcribed spacer 1 (ITS1) region. The $P$. pachyrhizi-specific probe ITS1PhpFAM1 (5'-FAM-TCATTGATTGATAAGATCTTTGGGCAATGG-3IABlkFQ) (Integrated DNA Technologies Coralville, IA) and reverse primer ITS1rustR3d (5'TGTGAGAGCCTAGAGATCCATTG) were designed by comparing sequences of the ribosomal DNA (rDNA) for rust fungal species listed in Table 1 using MacVector (MacVector, Inc., Cary, NC). The assay was performed in a $25-\mu$ final volume with $1 \times$ OmniMix (TaKaRa Bio Inc. by Cepheid), $0.5 \mu \mathrm{M}$ each primer, $0.2 \mu \mathrm{M}$ ITS1PhpFAM1, and $2 \mu \mathrm{l}$ of sample DNA. Cycling parameters were $95^{\circ} \mathrm{C}$ for $2 \mathrm{~min}$, followed by 45 cycles of $95^{\circ} \mathrm{C}$ for $5 \mathrm{~s}, 60^{\circ} \mathrm{C}$ for $30 \mathrm{~s}$, and $72^{\circ} \mathrm{C}$ for $30 \mathrm{~s}$.

The second assay evaluated was the assay developed by Frederick et al. (8). Assay conditions were followed as described.

The third assay was a nested assay combining the first two assays. The nested assay used the reverse primer Ppa2 specific to $P$. pachyrhizi (8) and a more general rust fungal forward primer ITS1rustF4a (5'-GAGGAAGTAAAAGTCGTAACAAGGTTTC) in the first round. The first-round amplification was performed in a final volume of $25 \mu \mathrm{l}$ containing $1 \times$ OmniMix, $0.5 \mu \mathrm{M}$ each primer, and $2 \mu \mathrm{l}$ of sample DNA. Cycling parameters were $95^{\circ} \mathrm{C}$ for $2 \mathrm{~min}$, followed by 20 amplification cycles of $95^{\circ} \mathrm{C}$ for $15 \mathrm{~s}$, $60^{\circ} \mathrm{C}$ for $30 \mathrm{~s}$, and $72^{\circ} \mathrm{C}$ for $30 \mathrm{~s}$. The amplicon was diluted 1:1000 in sterile water in two steps, 10:90 and 10:990, and immediately used as template for the second-round PCR. Cycling parameters for the second-round qPCR were identical to the con- ditions of the first assay but used $2 \mu$ of the diluted amplicon as the DNA template. All three assays were performed on a SmartCycler (Cepheid). Fluorescence data calculated by the SmartCycler software (ver. 2.0c) were collected at the end of each $60^{\circ} \mathrm{C}$ annealing step.

Controls for final assay. Each assay contained 15 rain samples, a positive control, and at least one negative control. The sources of $P$. pachyrhizi DNA for the positive control were different in 2005 and 2006 but were consistent throughout a year. In 2005, P. pachyrhizi DNA was obtained from spores collected from infected soybean leaves at the BL-3 facility at Fort Detrick, MD (access to infected plants courtesy of Dr. Reid Frederick, United States Department of Agriculture-Agricultural Research Service, Foreign Disease-Weed Science Research Unit, Fort Detrick, MD). Only DNA was removed from the facility and was shipped with APHIS permits to the CDL in St. Paul, MN for use in this study. In 2006, permits to work on infected tissue were obtained. $P$. pachyrhizi DNA was extracted from 20 individual infected soybean plants collected on 18 August 2005 from a sentinel plot in Marion County, FL by Dr. Carrie Lapaire Harmon (University of Florida, Gainesville) and sent to the CDL the same day. Dilutions of a single DNA sample were used for all assays in 2006.

For each set of 15 NADP/NTN filters, a blank filter was added during the filter-cutting phase as a control for contamination between cutting filters. When a NADP/NTN site either did not have precipitation over a weekly interval or precipitation was too

TABLE 1. List of rust fungal samples used to design and test fungal and rust specific primers and P. pachyrhizi specific TaqMan probe

\begin{tabular}{|c|c|c|c|c|c|}
\hline Rust species & Host & Origin & Source $^{\mathrm{a}}$ & Year & GenBank accession no. \\
\hline \multicolumn{6}{|c|}{ Phakopsora pachyrhizi } \\
\hline Australia $72-1^{\mathrm{b}}$ & Glycine $\max$ & Australia & 6 & 1972 & AF333488 \\
\hline Australia $79-1^{\mathrm{b}}$ & G. $\max$ & Australia & 6 & 1979 & AF333489 \\
\hline Hawaii $98^{b}$ & G. $\max$ & Hawaii & 6 & 1998 & AF333491 \\
\hline India $73-1^{\mathrm{b}}$ & G. $\max$ & India & 6 & 1973 & AF333492 \\
\hline Indonesia $72-1^{b}$ & G. $\max$ & Indonesia & 6 & 1972 & AF333493 \\
\hline Philippines $77-1^{\mathrm{b}}$ & G. $\max$ & Philippines & 6 & 1977 & AF333494 \\
\hline Taiwan $80-2^{\mathrm{b}}$ & G. $\max$ & Taiwan & 6 & 1980 & AF333497 \\
\hline Thailand $76-1^{\mathrm{b}}$ & G. $\max$ & Thailand & 6 & 1976 & AF333498 \\
\hline MUT Zimbabwe ${ }^{b}$ & G. $\max$ & Zimbabwe & 6 & 2000 & AF333499 \\
\hline TM Zimbabwe $\mathrm{e}^{\mathrm{b}}$ & G. $\max$ & Zimbabwe & 6 & 2000 & AF333500 \\
\hline $\mathrm{Php} 1^{\mathrm{c}}$ & G. $\max$ & NA & 6 & 2005 & $\ldots$ \\
\hline HSZ1685-A5 & G. $\max$ & Florida & 7 & 2005 & EU436700 \\
\hline HSZ1685-T5 & G. $\max$ & Florida & 7 & 2005 & EU436701 \\
\hline HSZ1689-A5 & G. $\max$ & Florida & 7 & 2005 & EU436706 \\
\hline HSZ1690-A5 & G. $\max$ & Florida & 7 & 2005 & EU436707 \\
\hline HSZ1690-T5 & G. $\max$ & Florida & 7 & 2005 & EU436708 \\
\hline HSZ1691-T5 & G. $\max$ & Florida & 7 & 2005 & EU436709 \\
\hline HSZ1692-T5 & G. $\max$ & Florida & 7 & 2005 & EU436710 \\
\hline HSZ1693-T5 & G. $\max$ & Florida & 7 & 2005 & EU436711 \\
\hline HSZ1694-T5 & G. $\max$ & Florida & 7 & 2005 & EU436712 \\
\hline HSZ1695-A5 & G. $\max$ & Florida & 7 & 2005 & EU436713 \\
\hline HSZ1695-T5 & G. $\max$ & Florida & 7 & 2005 & EU436714 \\
\hline HSZ1696-A5 & G. $\max$ & Florida & 7 & 2005 & EU436715 \\
\hline HSZ1696-T5 & G. $\max$ & Florida & 7 & 2005 & EU436716 \\
\hline HSZ1697-T5 & G. $\max$ & Florida & 7 & 2005 & EU436717 \\
\hline HSZ1698-A5 & G. $\max$ & Florida & 7 & 2005 & EU436718 \\
\hline HSZ1698-T5 & G. $\max$ & Florida & 7 & 2005 & EU436719 \\
\hline
\end{tabular}

${ }^{a}$ Samples from 1, Cereal Disease Laboratory, St. Paul, MN; 2, J. Markova, Charles University, Czech Republic; 3, Y. Ankister, Institute of Cereal Crops Improvement, Tel Aviv University, Israel; 4, X. Chen, United States Department of Agriculture-Agricultural Research Service (USDA-ARS), Pullman, WA; 5, A. F. Juusten, Department of Crop Protection, Danish Institute of Agricultural Sciences, Denmark, DNA; 6, R. Frederick, USDA-ARS, Foreign Disease-Weed Science Research Unit, Fort Detrick, MD; 7, C. Harmon, Department of Plant Pathology, University of Florida, Gainsville; and 8, N. Glynn, USDA-ARS, Canal Point, FL.

${ }^{\mathrm{b}}$ Used only in primer and probe design. DNA was not available.

${ }^{c}$ DNA extracted from infected soybean in BL3 containment facility at Ft. Detrick, MD. 
low to record, a blank filter was substituted (NADP blank) and assayed like any other sample. In 2005, nearly all NADP blanks were processed. However, in 2006, only three NADP blanks were processed per week (see Supplementary Tables for details).

Scoring a sample as positive. Assays were considered for scoring only if the positive control was positive and the negative control was negative. If these conditions were not met, the PCR assay was repeated or the data were not included. Rain samples were considered positive for P. pachyrhizi if the qPCR assay had a positive $\mathrm{C}_{\mathrm{T}}$ value, an $\mathrm{S}$-shaped amplification curve, and produced an $\approx 250$-bp-sized amplicon on a $1.0 \%$ agarose gel. The threshold for each reaction was set between 10 and 15 standard deviations above background fluorescence, calculated from cycle 1 through cycle 40. Statistical analysis of the frequency of detecting $P$. pachyrhizi spores over comparable weeks was done using a paired $t$ test (Statistix for Windows; Analytical Software, St. Paul, MN).

Assay evaluation. To determine the optimal assay, specificity and sensitivity of each of the three assays was compared. Assay specificity was evaluated using DNA from the same samples used to design the probe when available and from other species (Table 1). Sensitivity of each assay was evaluated using spore suspensions spotted on filters of $\leq 10,25,50,100$, and 500 spores made in sterile deionized water and Tween 20 using a hemacytometer to determine concentration. Each spore suspension was replicated in triplicate and each assay run on the same extraction.

After the optimal assay was determined, single spores were picked using dog hairs (24) to determine whether a single $P$. pachyrhizi spore could be detected and to calibrate the assay (see "Estimating spore load" below). A single spore was picked and examined microscopically before being placed directly into the DNA extraction tube. Each spore was placed directly into the DNA extraction tube and not onto a filter to ensure that a negative result was not due to a spore being trapped on the filter.

Verifying positive samples. To validate that the DNA of a positive reaction was from $P$. pachyrhizi, amplicons were separated by $1.0 \%$ agarose gel electrophoresis, stained with ethidium bromide, and visualized by UV transillumination. Furthermore, amplicons from several positive samples with moderate and high spore loads (see below) were cloned and sequenced on an automated DNA sequencer (LI-COR, Lincoln, NE). A minimum of three clones was sequenced for each sample, and the DNA sequence data was assembled and edited with Sequencer (Genecodes, Ann Arbor, MI). If more than one genotype was present, an additional three clones were sequenced. Consensus sequences were compared with other DNA sequences through BLASTN analysis of sequences available on the GenBank website (available online by the National Center for Biotechnology Information). Specific sequence comparisons were made between the amplicons from rain samples and other fungi to pinpoint sequence differences and determine whether the amplicon was derived from $P$ pachyrhizi by aligning sequences using MacVector (MacVector, Inc.).

Estimating spore load. To extrapolate the number of spores deposited per square meter over a given week, one spore, two

TABLE 1. (continued from preceding page)

\begin{tabular}{|c|c|c|c|c|c|}
\hline Rust species & Host & Origin & Source $^{\mathrm{a}}$ & Year & GenBank accession no. \\
\hline HSZ1699 & G. $\max$ & Florida & 7 & 2005 & $\ldots$ \\
\hline HSZ1700 & G. $\max$ & Florida & 7 & 2005 & $\ldots$ \\
\hline HSZ1701-T5 & G. $\max$ & Florida & 7 & 2005 & EU436720 \\
\hline HSZ1703-T5 & G. $\max$ & Florida & 7 & 2005 & EU436722 \\
\hline HSZ1704-T5 & G. $\max$ & Florida & 7 & 2005 & EU436723 \\
\hline \multicolumn{6}{|l|}{ P. meibomiae } \\
\hline $\mathrm{Phm}$ & G. $\max$ & NA & 6 & 2005 & $\cdots$ \\
\hline \multicolumn{6}{|c|}{ Puccinia andropogonis } \\
\hline HSZ0218 & Andropogon gerardii & Wisconsin & 1 & 1998 & $\ldots$ \\
\hline \multicolumn{6}{|l|}{ P. coronata } \\
\hline 93MN437 & Avena sativa & Minnesota & 1 & 1993 & AY114290 \\
\hline HSZ0786 & Bromus inermis & Minnesota & 1 & 2003 & $\ldots$ \\
\hline \multicolumn{6}{|l|}{ P. graminis } \\
\hline 78-21-BB463 & Triticum aestivum & Washington & 1 & 1978 & AY114289 \\
\hline \multicolumn{6}{|l|}{ P. hordei } \\
\hline HSZ0628 & Hordeum murium & Israel & 3 & 2002 & $\ldots$ \\
\hline P. kuehnii & Saccharum officinarum & Florida & 8 & 2007 & $\ldots$ \\
\hline \multirow{2}{*}{\multicolumn{6}{|c|}{ P. recondita }} \\
\hline & & & & & \\
\hline 91TX9503 & Secale cereale & Texas & 1 & 1991 & DQ417422 \\
\hline HSZ0698 & S. cereale & Czech Republic & 2 & 2002 & DQ417423 \\
\hline ANK9958 & Aegilops ovata & Israel & 3 & 2002 & DQ417424 \\
\hline ANK9974 & A. variabilis & Israel & 3 & 2003 & AY187088 \\
\hline \multicolumn{6}{|l|}{ P. striiformis } \\
\hline PST78 & T. aestivum & Washington & 4 & 2001 & DQ417396 \\
\hline $22 / 99$ & T. aestivum & Denmark & 5 & 1999 & DQ417397 \\
\hline $52 / 99^{b}$ & T. aestivum & Denmark & 5 & 1999 & DQ417404 \\
\hline HSZ0722 & T. aestivum & Texas & 1 & 2003 & DQ417405 \\
\hline
\end{tabular}


spores, and five spores were assayed following the nested qPCR protocol. Individual spores were picked using dog hair as described above. Placing spores in tubes directly, rather than on filters, was done to ensure that a known number of spores were assayed. Logarithmic and power curves (Fig. 2A and B, respectively) were fitted to the average $C_{T}$ value of each spore number ( $n=11, n=5$, and $n=4$ for one, two, and five spores, respectively) using Delta Graph 5.6 (Red Rock Software, Salt Lake City, UT). Both models were used to estimate spore loads from $\mathrm{C}_{\mathrm{T}}$ values (Fig. $2 \mathrm{C}$ ). Some $\mathrm{C}_{\mathrm{T}}$ values of the two-spore DNA extracts were not included in the average because they were noticeably higher than others, matching $\mathrm{C}_{\mathrm{T}}$ values from one spore, and most likely resulted from DNA not being obtained from both spores. It was not feasible to run standard curves for each assay because the DNA extracts from one and two spores were unstable over just a few days time, even when stored at -20 or $-80^{\circ} \mathrm{C}$, and practically could not be made new each day. Therefore, the fitted curves were used to estimate spore load for all samples. When model estimates differed by more than a few spores per square meter, a range was given using both equations. Otherwise, values obtained from the logarithmic equation were used.

Genotypic variation. The primary objective in sequencing a subset of rain samples testing positive for $P$. pachyrhizi was to verify the nested qPCR assay. However, an amplicon (ITS1) sequence of $P$. pachyrhizi from rain samples was also used to estimate genotypic variation within the rain collected over the soybean-growing regions of the continental United States. Additionally, infected soybean leaves were collected at 20 points in a single sentinel plot in Marion County, FL, by Dr. Carrie Lapaire Harmon (University of Florida) (Table 1) for the purpose of providing a positive DNA control for the nested qPCR assay. These samples were also used to estimate the genetic variation of the ITS1 region within a single field. DNA was extracted from infected leaves from the sentinel plot using the same methods as for the rain filters. Nuclear rDNA was PCR amplified in a 50- $\mu 1$ reaction mixture as described by Anikster et al. (1). DNA sequencing reactions were preformed using a Thermo Sequenase Primer Cycle sequencing kit (GE Healthcare Bio-Sciences Corp., Piscataway, NJ) and analyzed on an automated DNA sequencer (LI-COR). A minimum of three clones was sequenced for each sample and the DNA sequence data was assembled and edited with Sequencer (Genecodes). Nucleotide sequence data have been submitted to GenBank, with the accession numbers listed in Tables 1 and 2. The variation in ITS1 sequence among the 13 sequences from GenBank, 18 of the 20 DNA samples of infected soybean leaves from the Florida sentinel plot, and a subset of positive rain samples in 2005 and 2006 were aligned using MacVector (version 9.0; MacVector Inc.). Polymorphic sites were considered legitimate if they occurred in more than two samples.

Disease development with LDD. Positive samples were plotted using GPS coordinates of the individual NADP/NTN sites in ArcGIS 9.1 (ESRI, Redlands, CA). To analyze incidence of LDD, samples testing positive for $P$. pachyrhizi were correlated with jumps in counties reporting SBR in the field using ArcGIS to measure distances between counties reporting SBR. Four individual reports of disease greater than $100 \mathrm{~km}$ from the next nearest county or parish report were mapped beginning 20 August 2006. Contour maps were constructed using Adobe Photoshop CS 8.0 (Adobe Systems Incorporated, San Jose, CA).

\section{RESULTS}

Assay evaluation. Specificity of the nested assay was evaluated using DNA from a variety of rust fungal species (Table 1). In all cases, the assay detected only $P$. pachyrhizi. Specificity of the two non-nested assays has been previously shown $(2,8)$, with the modified ITS1rustR3d primer showing the same specificity as ITS1rustR3c (2). Specificity of the ITS1PhpFAM1 TaqMan probe was further evaluated by BLASTN analysis. In addition to matching to $P$. pachyrhizi, the next closest match to the TaqMan probe was to a protozoan (Tetrahymena thermophila) with only $63 \%$ similarity.

Spore suspensions of $\leq 10,25,50,100$, and 500 spores were created to evaluate all three assays. Both single-round assays performed equally well down to 25 spores/filter, but neither detected $P$. pachyrhizi DNA as consistently as the nested assay at the $\leq 10$ spores/filter concentration. The nested assay detected $P$. pachyrhizi in every case where the two single-round assays did not. The results also indicated that the protocol for removing spores from filters was effective at low spore concentrations.
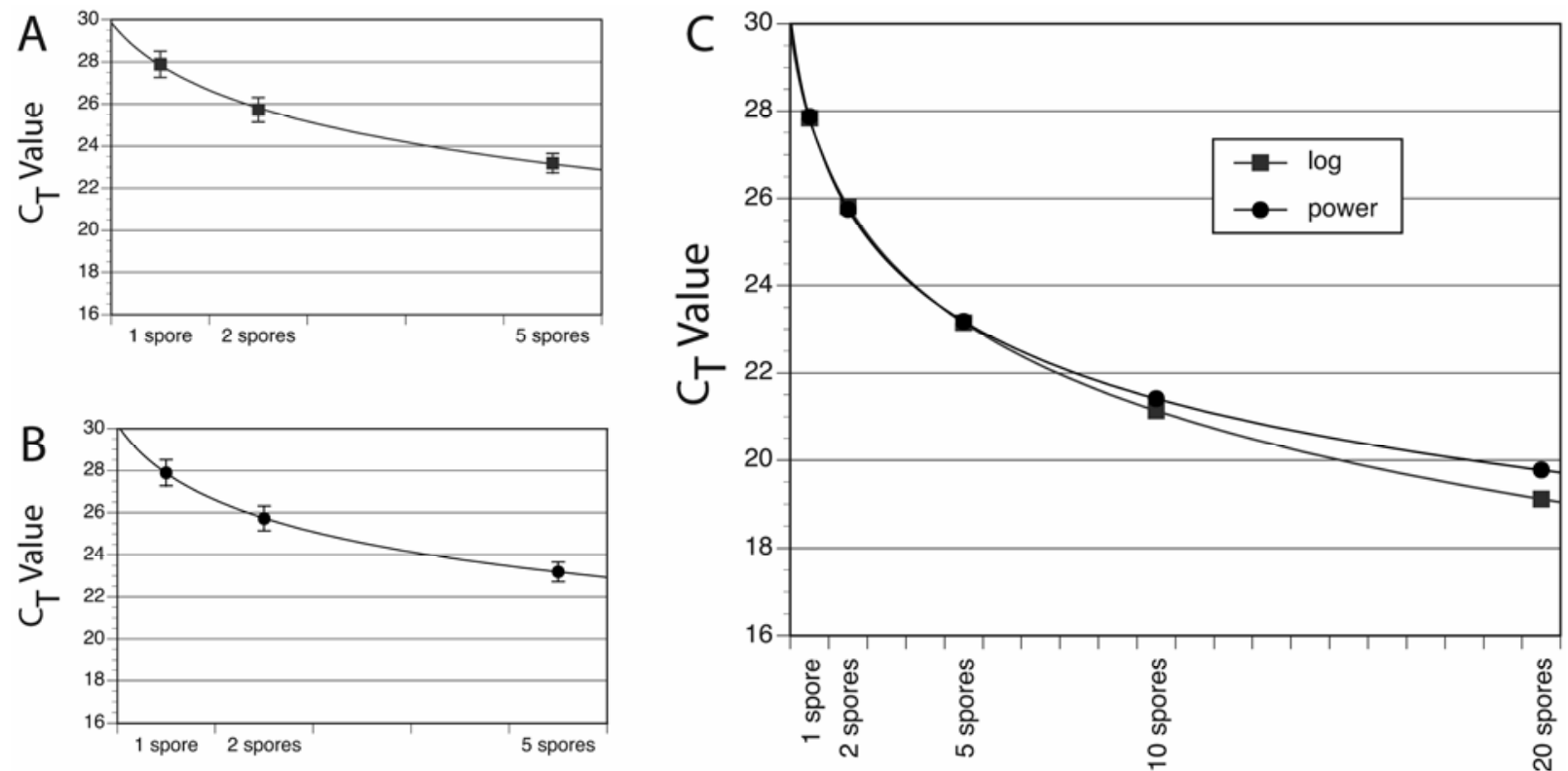

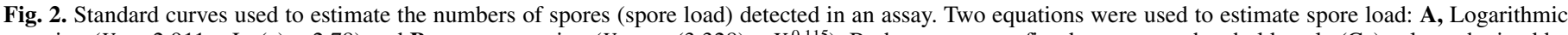

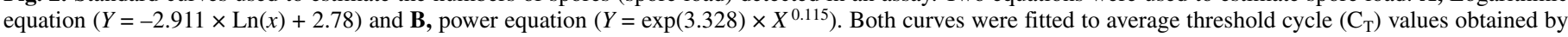

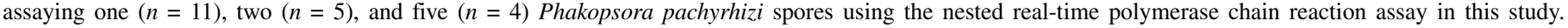

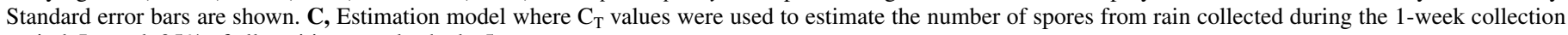
period. In total, $95 \%$ of all positive samples had $\leq 5$ spores. 
Because the two single-round assays did not always detect $\leq 10$ spores/filter, only the nested assay was evaluated for P. pachyrhizi spores picked with dog hair. In this experiment, single spores were detected $67 \%$ of the time with the nested assay.

Picking single spores with dog hair was also used to calibrate the assay to estimate the number of spores detected in rain samples. The logarithmic equation (Fig. 2A) was used to estimate the spore load for spore suspensions of $\leq 10$, originally used to evaluate all three assays. The results $(n=30$, mean $=4.0$, standard deviation $=3.1$, minimum $=0.9$, maximum $=15.5$ ) suggest that placing spores directly in tubes rather than on filters was appropriate for calibrating the assay.

Verifying positive samples. In all, 1,461 rain samples were collected in 2005 and 2,145 samples were collected in 2006. All samples with a positive $\mathrm{C}_{\mathrm{T}}$ value were analyzed by gel electrophoresis. Amplicons of the expected size $(\approx 250 \mathrm{bp})$ were observed on $1.0 \%$ agarose gels for all samples testing positive with the $P$. pachyrhizi qPCR assay and with an S-shape amplification curve. As expected, samples with higher spore loads (lower $\mathrm{C}_{\mathrm{T}}$ values) had amplicons with brighter fluorescence. Occasionally, a sample with a low spore load score did not result in a visible amplicon on the accompanying agarose gel and was scored as negative.

In total, 6 and 31 randomly chosen rain samples that had $>20$ spores $/ \mathrm{m}^{2}$ were sequenced in 2005 and 2006, respectively. All 37 DNA samples were found to be from $P$. pachyrhizi based on sequence alignments and BLASTN results.

Detection frequency. There was a significant increase in the number of rain samples testing positive for $P$. pachyrhizi per week in 2006 compared with 2005 over the same time frame (paired $t=$ $4.45, \mathrm{DF}=15, P=0.0005)$, with no significant difference in the number of rain samples assayed (paired $t=0.97, \mathrm{DF}=15, P=$ 0.35 ). Of the 1,461 rain samples assayed in 2005 from the 121 NADP sites, 76 were positive for $P$. pachyrhizi. In 2006, over the same time period from 9 May through August, 268 of the 1,509 rain samples assayed tested positive. As a percentage, $5.2 \%$ of the assays showed positive results for $P$. pachyrhizi in 2005, and $17.8 \%$ in 2006 over the same time period.

A bimodal pattern of detecting positive rain samples was found in both years. The number of positive samples increased in May, decreased in mid-June to mid-July, and increased again in late July (Fig. 3). In 2005, the number of positive samples began to decline in mid-August. In 2006, the number of samples testing positive for $P$. pachyrhizi was still high at the end of August and did not decline until mid-September. From the beginning of September through 17 October 2006, 636 rain samples were assayed for $P$. pachyrhizi. The total number of rain samples assayed in 2006 increased to 2,145 and the total number of samples testing positive for $P$. pachyrhizi increased to 327 samples (15.2\%). The bimodal pattern of detecting positive samples was not the result of matching increases and decreases to the frequency of rainfall. Although, in 2005 there was a decrease in the number of sites with rain in mid-June, there was no difference in the number of sites with measurable rain in any other month and no pattern at all in 2006 (data not shown).

Detection distribution. $P$. pachyrhizi was detected across the U.S. soybean-growing region in both 2005 and 2006 (Fig. 4A and $\mathrm{B}$, respectively). Also common between years was a band of lowfrequency detection of $P$. pachyrhizi spores in rain from South Carolina directly west to northern Texas. However, in 2005, the majority of the rain samples testing positive for $P$. pachyrhizi were in the southern United States, south of the Ohio River. In 2006, there was a high frequency of positives along the Gulf Coast and Texas but also an increase in the frequency of samples testing positive for $P$. pachyrhizi north and northwest of the Ohio River compared with 2005. The increase in frequency of detection and higher spore loads in the upper Midwest corresponds to the change in disease reports between years (Fig. 4A and B) (Inte- grated Pest Management-Pest Information Platform for Extension and Education [IPM PIPE] website).

Each year in the first 2 weeks of the study, spore deposition in rain was primarily in the southern United States. In 2005, the pattern was observed by detection alone whereas, in 2006, relatively higher spore loads were detected in the southern United

TABLE 2. List of genotypes found from a subset of rain samples with Phakopsora pachyrhizi spores

\begin{tabular}{|c|c|c|c|}
\hline Date $^{\mathrm{a}}$ & Site $^{b}$ & Genotype $^{c}$ & Accession no. \\
\hline \multirow[t]{2}{*}{28 June 2005} & WI28 & $\mathrm{T} 4$ & EU584435 \\
\hline & & T5 & EU584436 \\
\hline 5 July 2005 & MO05 & T5 & EU584437 \\
\hline \multirow[t]{2}{*}{26 July 2005} & MN27 & $\mathrm{T} 4$ & EU584438 \\
\hline & & T5 & EU584439 \\
\hline 9 August 2005 & ND08 & T5 & EU584440 \\
\hline 23 August 2005 & IN41 & T5 & EU584441 \\
\hline 23 August 2005 & SD99 & A6 & EU584442 \\
\hline \multirow[t]{5}{*}{16 May 2006} & GA99 & A5 & EU584443 \\
\hline & & $\mathrm{T} 4$ & EU584444 \\
\hline & & T5 & EU584445 \\
\hline & LA12 & T5 & EU584446 \\
\hline & VA24 & T5 & EU584447 \\
\hline \multirow[t]{11}{*}{23 May 2006} & FL99 & A5 & EU584448 \\
\hline & & T5 & EU584449 \\
\hline & IL63 & A5 & EU584450 \\
\hline & & T5 & EU584451 \\
\hline & KY03 & T5 & EU584452 \\
\hline & MI51 & A5 & EU584453 \\
\hline & & $\mathrm{T} 4$ & EU584454 \\
\hline & & T5 & EU584455 \\
\hline & NC41 & A5 & EU584456 \\
\hline & & C5 & EU584457 \\
\hline & & T5 & EU584458 \\
\hline \multirow[t]{6}{*}{30 May 2006} & KS07 & A5 & EU584459 \\
\hline & & T5 & EU584460 \\
\hline & TNO0 & A5 & EU584461 \\
\hline & & T5 & EU584462 \\
\hline & VA13 & A5 & EU584463 \\
\hline & & T5 & EU584464 \\
\hline \multirow{11}{*}{6 June 2006} & GA99 & A5 & EU584465 \\
\hline & & T5 & EU584466 \\
\hline & KS07 & T5 & EU584467 \\
\hline & & T6 & EU584468 \\
\hline & MN01 & T5 & EU584469 \\
\hline & OH09 & T5 & EU584470 \\
\hline & SD08 & $\mathrm{T} 4$ & EU584471 \\
\hline & & T5 & EU584472 \\
\hline & TN04 & A5 & EU584473 \\
\hline & & T5 & EU584474 \\
\hline & TX22 & T5 & EU584475 \\
\hline \multirow[t]{3}{*}{13 June 2006} & MN23 & T5 & EU584476 \\
\hline & $\mathrm{NC} 03$ & A5 & EU584477 \\
\hline & OH09 & T5 & EU584478 \\
\hline \multirow[t]{3}{*}{20 June 2006} & IL18 & A5 & EU584479 \\
\hline & KS32 & $\mathrm{T} 4$ & EU584480 \\
\hline & & T5 & EU584481 \\
\hline \multirow[t]{6}{*}{27 June 2006} & MO03 & A5 & EU584482 \\
\hline & & C5 & EU584483 \\
\hline & & $\mathrm{T} 4$ & EU584484 \\
\hline & & T5 & EU584485 \\
\hline & MO43 & T5 & EU584486 \\
\hline & SC05 & T5 & EU584487 \\
\hline \multirow[t]{3}{*}{25 July 2006} & PA15 & T5 & EU584488 \\
\hline & TX03 & $\mathrm{T} 4$ & EU584489 \\
\hline & & T5 & EU584490 \\
\hline \multirow[t]{5}{*}{1 August 2006} & AL99 & T5 & EU584491 \\
\hline & IA 23 & A5 & EU584492 \\
\hline & & T5 & EU584493 \\
\hline & MI52 & $\mathrm{T} 4$ & EU584494 \\
\hline & & T5 & EU584495 \\
\hline
\end{tabular}

${ }^{a}$ Date precipitation was collected. Precipitation was collected at weekly intervals.

${ }^{\mathrm{b}}$ National Atmospheric Deposition/National Trends Network sites.

${ }^{c}$ The letter corresponds to the nucleotide of the single nucleotide polymorphism followed by the number of TA simple sequence repeats (Fig. 5). 
States during the same time frame (Table 3). From 10 to 17 May 2005, rain samples that tested positive for $P$. pachyrhizi were found in South Carolina and Texas at relatively low spore load levels. During the second week, 17-24 May 2005, low spore load samples were found in South Carolina and twice in Tennessee. For the week of 9-16 May 2006, moderate spore loads were detected in Georgia, Louisiana, and Virginia, with low spore loads detected in Kansas, Kentucky, and Pennsylvania. During the second week in 2006 (16-23 May), moderate spore loads were detected in Florida, Illinois, Kentucky, Michigan, and North Carolina. Low spores loads for the second week in 2006 were found in Illinois, Indiana, Minnesota, Missouri, twice in North Carolina, and in Ohio (Table 3). Overall, P. pachyrhizi spores were detected more frequently and at higher levels in 2006 than in 2005 (Table 4).

To observe the relationship of LDD of spores and disease incidence, reports of disease greater than $100 \mathrm{~km}$ from the next nearest county or parish report were mapped beginning 20 August 2006 (Fig. 4C). The distribution of positive samples with $>20$ spores $/ \mathrm{m}^{2}$ in August and September showed two generalized pathways for LDD, one along the east coast and the other up along the Mississippi River toward Iowa, Illinois, Indiana, and western Ohio. These two pathways correspond to the field reports reported by PIPE of SBR in the field in September and October. SBR was first reported in Kentucky on 11 October 2006 (Fig. 4C). Rain collected on 19 and 26 September tested positive for $P$.

A
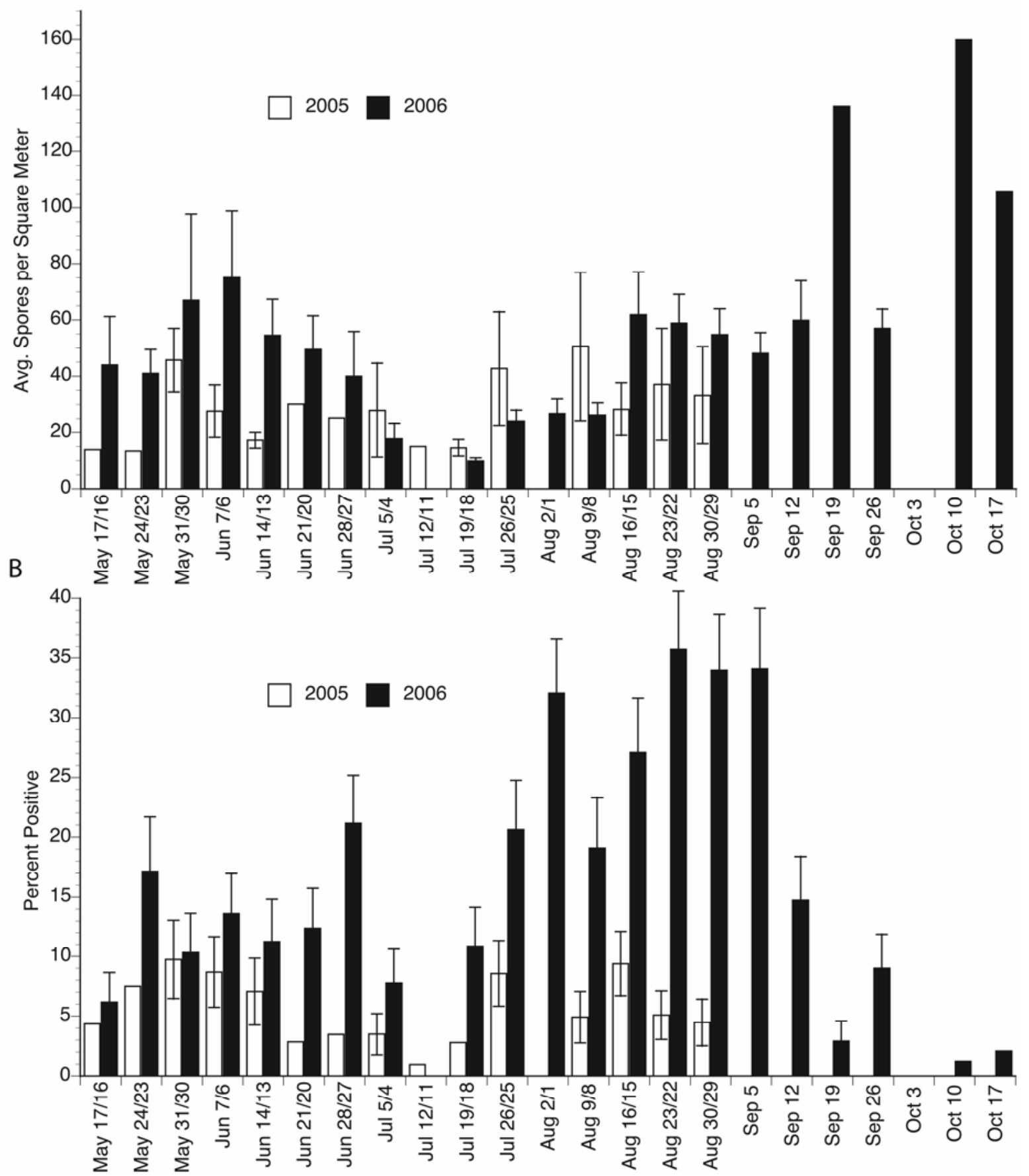

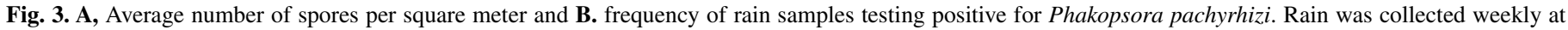

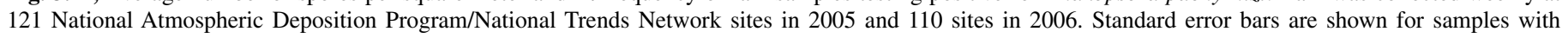
$>3$ data points only. Dates in the $\mathrm{x}$-axis represent 2005/2006, respectively. 
pachyrhizi at an NADP site (KY99) in the same county as the SBR report. The sample on 19 September was the third highest spore load recorded that year (317 to 361 spores $/ \mathrm{m}^{2}$, log and power equations, respectively), while the sample collected on 26 September had $\approx 78$ spores $/ \mathrm{m}^{2}$.

To examine possible differences between the two generalized pathways, NADP sites were divided into eastern and western groups along $85^{\circ} \mathrm{W}$ longitude to make two equal groups (Fig. $4 C)$. There was an easterly shift in the frequency of spore load positives $>20$ spores $/ \mathrm{m}^{2}$ from August through September 2006. In the 5 weeks of August, four of five showed higher frequency of detection of $P$. pachyrhizi spores in the western half of the study compared with the eastern half. In September, the percentage of sites in the eastern half of the study were always higher compared with sites in the western half of the study (Fig. 4D).

Genotypic variation. To estimate genotypic variation among $P$. pachyrhizi found in rain, two genotypic markers were observed from 98 sequences: 24 sequences from 18 infected soybean leaf samples from the Florida sentinel plot, 13 sequences from GenBank, 8 sequences from 6 rain samples in 2005, and 53 sequences from 31 rain samples in 2006. A single nucleotide polymorphism and simple sequence repeats were used to create a genotype designation and resulted in six different genotypes for all sequences (Fig. 5).

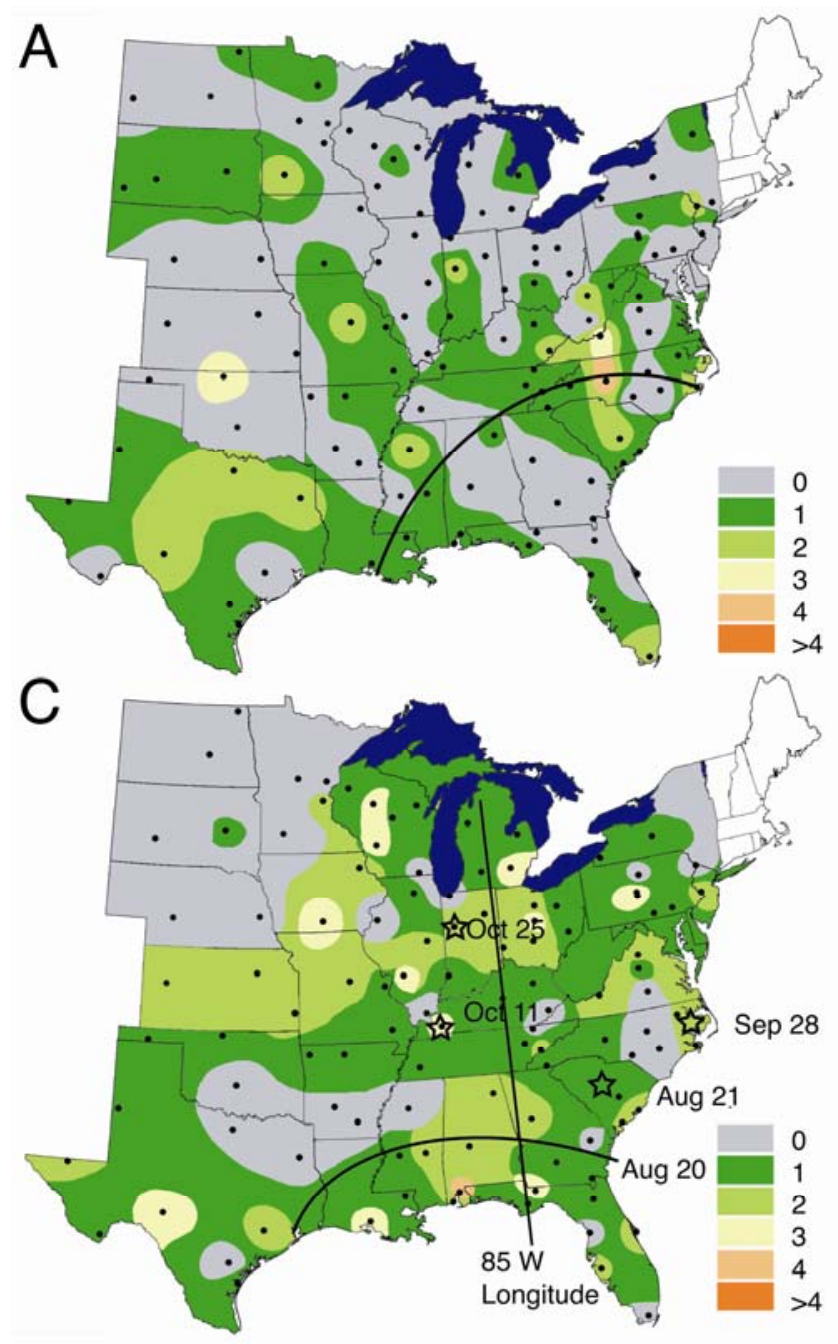

Two genotypes were found in the single sentinel plot in Florida. In all, $61 \%(11 / 18)$ of the samples were of the T5 genotype, 1 of 18 samples had the A5 genotype alone, and the remaining 6 samples (6/18) had both genotypes. These two genotypes were also found in sequence available in GenBank (Table 1) and were the most common genotypes found in the rain samples (Fig. 5).

DNA was sequenced from 6 positive rain samples in 2005 and 31 in 2006. All were found to be from $P$. pachyrhizi, confirming the results of the nested qPCR assay. Two predominant genotypes, A5 and T5, were found across the study area. However, four other genotypes were also observed. Two of these genotypes, A6 and T6, correspond to sequences found in GenBank, while genotypes T4 and C5 were unique (Fig. 5). Of the six samples testing positive for $P$. pachyrhizi in 2005, three genotypes were found, and two of the six samples had two genotypes. In 2006, 18 of the 31 samples had more than one genotype (Table 2). Of those samples with more than one genotype, 15 had two genotypes, 3 had three genotypes, and 1 sample had four genotypes. The sample with four genotypes was found in Missouri the week ending 27 June 2006.

\section{DISCUSSION}

The first objective of this study was to develop a qPCR assay that would be sensitive and accurate enough to detect a single $P$.
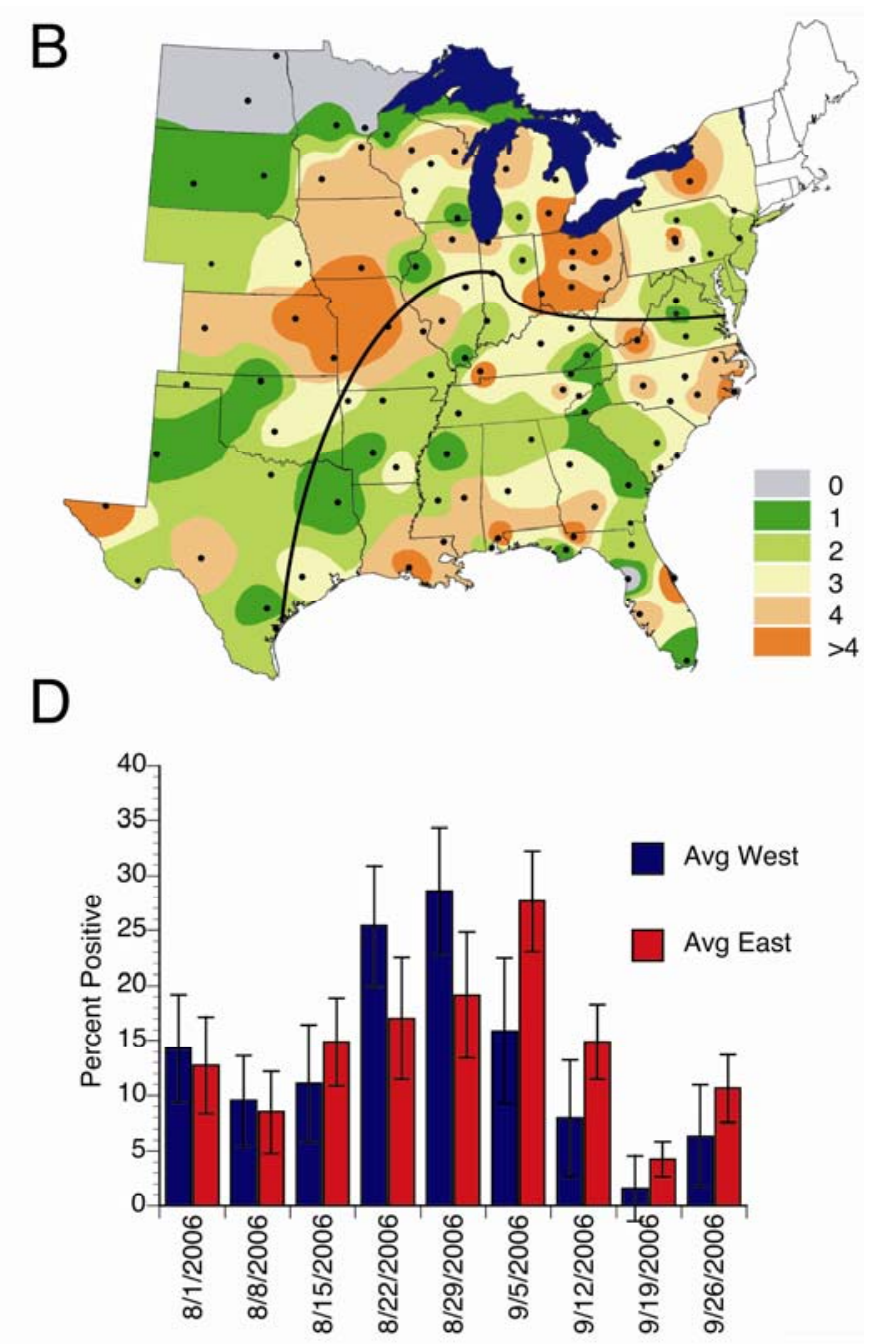

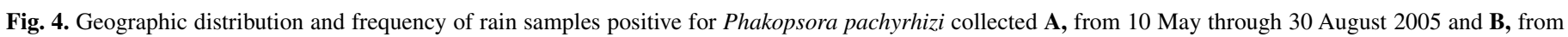

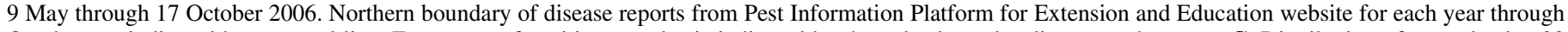

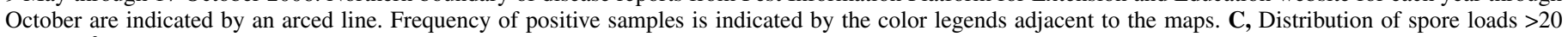

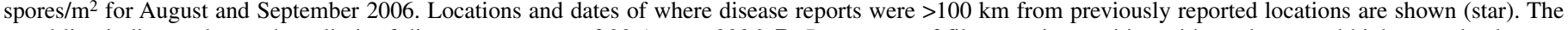

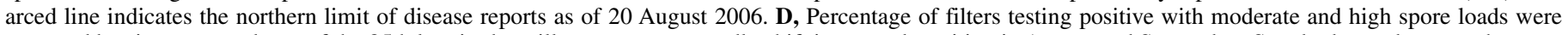
averaged by sites west and east of the 85th longitude to illustrate an eastwardly shift in spore deposition in August and September. Standard error bars are shown. 
pachyrhizi spore. In laboratory simulations, the assay detected a single $P$. pachyrhizi spore in roughly two out of three instances, and $\geq 2$ spores $100 \%$ of the time, demonstrating the sensitivity of the assay. The implication then was that the assay could be used to detect the primary deposition of inoculum of SBR. The strength of the nested assay was that it was based on two levels of specificity in the primers and in a TaqMan probe, with the shape of the amplification curve and amplicon size used to confirm positive $\mathrm{C}_{\mathrm{T}}$ values. To further evaluate accuracy, $\mathrm{qPCR}$ amplicons from 37 rain samples, 6 from 2005 and 31 from 2006, with a positive assay score were sequenced. All the rain samples were $P$. pachyrhizi based on sequence alignment, proving the accuracy of the assay. These results indicate that the assay developed in this study is useful in detecting spores deposited in rain, and that it was sensitive enough to detect the first deposition of spores into a given area due to LDD, as well as subsequent local spore transport.

With a reliable assay in hand, the second objective of this study was to monitor rainfall for $P$. pachyrhizi spores and assess deposition patterns over the soybean-growing areas of the central United States. In this study, $>1,400$ rain samples were assayed for P. pachyrhizi in 2005 and $>2,100$ in 2006 at more than 100 NADP/NTN locations in 29 and 28 states, respectively, each year
(Fig. 3). As expected, based on the fact that SBR was first observed in the continental United States in the fall of 2004 (26), fewer rain samples were detected with $P$. pachyrhizi spores in 2005 than in 2006. The roughly threefold increase in the percentage of rain samples with $P$. pachyrhizi spores indicates an increase in incidence or severity of infected hosts in the inoculum source regions. Furthermore, the bimodal pattern found both years, with an increased frequency of detection first in late May

TABLE 4. Summary of spore load of weekly rain collections in 2005 and 2006 ${ }^{\mathrm{a}}$

\begin{tabular}{lcccc}
\hline Year & Low $^{\mathrm{b}}$ & Moderate $^{\mathrm{c}}$ & High $^{\mathrm{d}}$ & Very high $^{\mathrm{e}}$ \\
\hline 2005 & & & & \\
Number & 49 & 19 & 8 & 0 \\
Percent & 64 & 29 & 7 & 0 \\
2006 & & & & 11 \\
Number & 118 & 155 & 43 & 3 \\
Percent & 36 & 48 & 13 & \\
\hline
\end{tabular}

a All spore load estimates were done using the logarithmic equation $Y=$ $-2.911 \times \operatorname{Ln}(x)+2.78$

b Low spore load corresponded to $<20$ spores $/ \mathrm{m}^{2}$.

c Moderate spore load corresponded to 20 to 80 spores $/ \mathrm{m}^{2}$.

${ }^{\mathrm{d}}$ High spore load corresponded to 81 to $200 \mathrm{spores} / \mathrm{m}^{2}$.

e Very high spore load corresponded to $>201 \mathrm{spores} / \mathrm{m}^{2}$.

TABLE 3. List of positive rain samples by state and date

\begin{tabular}{|c|c|c|}
\hline Date $^{\mathrm{a}}$ & No. ${ }^{b}$ & States where Phakopsora pachyrhizi spores were detected in rain ${ }^{\mathrm{c}}$ \\
\hline \multicolumn{3}{|l|}{2005} \\
\hline May 17 & 2 & $\mathrm{SC}, \mathrm{TX}$ \\
\hline May 24 & 3 & $\mathrm{SC}, \mathrm{TN}(2)$ \\
\hline May 31 & 8 & $T X, N C, \underline{\mathrm{TX}}(2), \mathrm{VI}, \mathrm{MN}, \mathrm{TX}(2)$ \\
\hline June 7 & 8 & $\underline{\mathrm{IA}}, \mathrm{MO}, \mathrm{NC}, \mathrm{AL}, \mathrm{AR}, \mathrm{FL}(3)$ \\
\hline June 14 & 6 & $\underline{\mathrm{NC}}, \mathrm{KY}, \mathrm{MO}, \mathrm{OK}, \mathrm{WV}(2)$ \\
\hline June 21 & 2 & $\underline{\mathrm{IN}}, \mathrm{OK}$ \\
\hline June 28 & 3 & WI, NY, VA \\
\hline July 5 & 4 & $\underline{\mathrm{MO}}, \mathrm{TN}, \mathrm{TX}, \mathrm{VA}$ \\
\hline July 12 & 1 & $\overline{\mathrm{NC}}$ \\
\hline July 19 & 3 & $\underline{\mathrm{SC}}, \mathrm{FL}, \mathrm{SC}$ \\
\hline July 26 & 9 & $\overline{M N}, S D, \underline{\mathrm{PA}}, \mathrm{KY}, \mathrm{MN}, \mathrm{MO}, \mathrm{PA}(2), \mathrm{VA}$ \\
\hline August 2 & 0 & \\
\hline August 9 & 5 & $N D, \underline{\mathrm{NC}}(2), \mathrm{MS}, \mathrm{NC}$ \\
\hline August 16 & 11 & $M I, \underline{\mathrm{KY}}, \mathrm{MN}, \mathrm{NC}, \mathrm{KY}, \mathrm{MS}, \mathrm{NC}, \mathrm{OH}, \mathrm{OK}, \mathrm{WV}, \mathrm{TX}$ \\
\hline August 23 & 6 & $S D, \underline{\mathrm{IN}}, \mathrm{AL}(2), \mathrm{FL}, \mathrm{SD}$ \\
\hline August 30 & 5 & $P A, \underline{\mathrm{VA}}, \mathrm{IN}, \mathrm{TX}(2)$ \\
\hline \multicolumn{3}{|l|}{2006} \\
\hline May 16 & 6 & $L A, V A, \underline{\mathrm{GA}}, \mathrm{KS}, \mathrm{KY}, \mathrm{PA}$ \\
\hline May 23 & 12 & $K Y, \underline{\mathrm{FL}}, \mathrm{IL}(2), \mathrm{IN}, \mathrm{OH}, \mathrm{MI}, \mathrm{MN}, \mathrm{NC}(2), \mathrm{MO}, \mathrm{NC}$ \\
\hline May 30 & 9 & $\boldsymbol{V A}, T N, \underline{\mathrm{KS}}, \mathrm{KY}, \mathrm{MI}, \mathrm{MN}, \mathrm{MI}, \mathrm{NY}(2)$ \\
\hline June 6 & 14 & $\boldsymbol{O H}, P A, S D, \underline{\mathrm{GA}}, \mathrm{KS}, \mathrm{MN}, \mathrm{OH}(2), \mathrm{OK}, \mathrm{TN}, \mathrm{TX}, \mathrm{WI}, \mathrm{FL}, \mathrm{MI}$ \\
\hline June 13 & 9 & $K Y, M N, N C, O H, \underline{\mathrm{NC}, \mathrm{NY}, \mathrm{TX}}, \mathrm{OH}, \mathrm{NC}$ \\
\hline June 20 & 12 & $I L, K Y, \underline{\mathrm{FL}, \mathrm{GA}}(2), \mathrm{KS}(2), \mathrm{MS}, \mathrm{NC}, \mathrm{NE}, \mathrm{GA}, \mathrm{LA}$ \\
\hline June 27 & 22 & $S C, M O, \underline{\mathrm{IA}}, \mathrm{MO}, \mathrm{OH}, \mathrm{PA}, \mathrm{NY}, \mathrm{TX}, \mathrm{AL}, \mathrm{AR}(3), \mathrm{FL}, \mathrm{MO}, \mathrm{NC}(4), \mathrm{OH}(4)$ \\
\hline July 4 & 7 & $\underline{\mathrm{PA}}, \mathrm{IN}, \mathrm{KS}, \mathrm{MI}, \mathrm{PA}, \mathrm{SC}, \mathrm{WI}$ \\
\hline July 11 & 0 & \\
\hline July 18 & 10 & AR, IN, KS, KY (2), MN (2), MO, OH, OK \\
\hline July 25 & 20 & 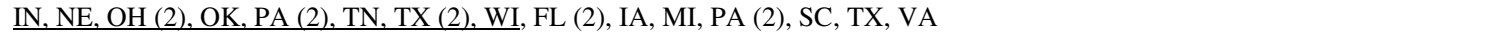 \\
\hline August 1 & 34 & 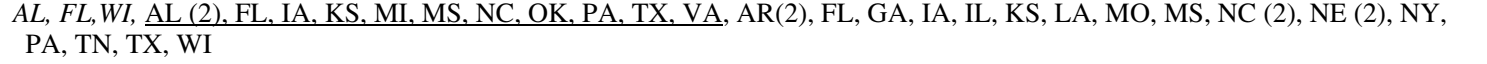 \\
\hline August 8 & 17 & FL, IN, KS, NJ, OH (2), TX (2), WI, IA, OH, TX (3), VA, WI (2) \\
\hline August 15 & 26 & 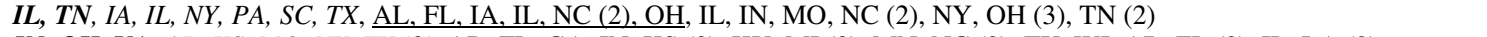 \\
\hline August 22 & 35 & 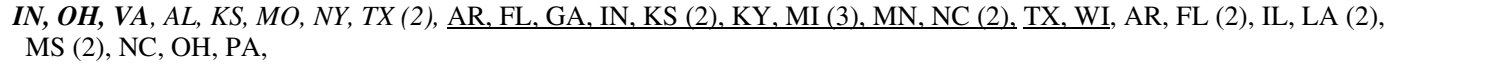 \\
\hline August 29 & 35 & TN, $O H, T N, T X, W I$, AL, FL, IL, IN (3), KY (2), LA (2), MI (3), MN, MO (3), MS, NJ, OH (3), OK, WI (2), AL, FL, KY, MN, WI \\
\hline September 5 & 30 & 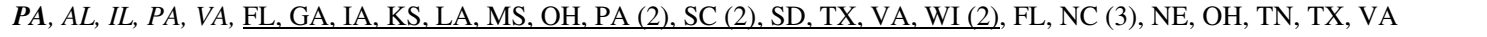 \\
\hline September 12 & 14 & $A L, G A, V A, \underline{\mathrm{AL}}, \mathrm{AR}, \mathrm{FL}, \mathrm{GA}, \mathrm{IA}, \mathrm{LA}, \mathrm{NC}, \mathrm{OH}, \mathrm{SC}, \mathrm{OH}, \mathrm{OK}$ \\
\hline September 19 & 3 & $\boldsymbol{K} \boldsymbol{Y}, \underline{\mathrm{FL}, \mathrm{MI}}$ \\
\hline September 26 & 9 & $P A, \underline{\mathrm{AL}, \mathrm{IL}}, \mathrm{KY}, \mathrm{OH}, \mathrm{PA}(2), \mathrm{SC}, \mathrm{WI}$ \\
\hline October 3 & 0 & \\
\hline October 10 & 1 & $N C$ \\
\hline October 17 & 2 & $I L, T X$ \\
\hline
\end{tabular}

\footnotetext{
${ }^{a}$ Date precipitation was removed from the National Atmospheric Deposition collector. Precipitation was collected each week.

b Number of rain samples testing positive for a given week.

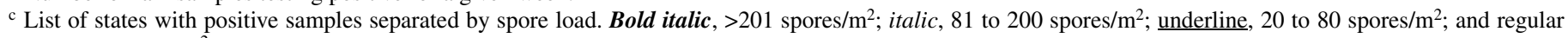
text, $<20$ spores $/ \mathrm{m}^{2}$ based on the $\log$ model. Parentheses indicate multiple sites within a state with the same spore load range.
} 
and then a larger increase in the beginning of August, suggests a possible shift of the primary inoculum sources from, primarily, the weedy legume kudzu in the spring to soybean. The larger increase in August likely reflects the increase in soybean availability and, perhaps, susceptibility. The roughly threefold increase in frequency of detecting P. pachyrhizi spores in rain in 2006 mirrored the increase, also roughly threefold, in the number of counties or parishes reporting detection of SBR in the field (PIPE website). The field reports do support the findings of this study that more inoculum was being distributed in 2006 compared with 2005 over a larger area and for a longer period of time.

The results of this study showed that frequency of deposition and relatively higher spore numbers of $P$. pachyrhizi spores were primarily in the southern United States in May and early June both years, but moved further north sooner in 2006 relative to 2005. These findings are consistent with models by Pivonia and Yang (20) that suggested that spore sources would be restricted to the most southern parts of Florida and Texas and also Mexico in the winter and spring months. Specific NADP/NTN sites positive for $P$. pachyrhizi in this study have been used in HYSPLIT back trajectory models and showed that the source of spores matched those predicted (13). However, P. pachyrhizi spore deposition was not entirely restricted to the southern United States. By the end of May in 2005 and more so in 2006, P. pachyrhizi spores were detected as far north as Minnesota, Illinois, Indiana, Michigan, Ohio, and Pennsylvania, but at lower frequency and spore numbers. Rowell and Romig (25) found $P$. graminis and $P$. triticina in rain samples in Minnesota in early May in 1963 and 1964.

There was a general trend of $P$. pachyrhizi spores being deposited further north and west in 2006 compared with 2005. In 2005 , most of the sites where $P$. pachyrhizi spores were detected were south of the Ohio River. However, P. pachyrhizi spores were also detected with relatively high frequency in Texas and Oklahoma both years (Fig. 3A and B). These findings suggest that inoculum sources were not restricted to the southeastern United States. To evaluate spore deposition in the central plain states, with inoculum sources potentially in Texas or Mexico, frequency of detection at sites east and west of $85^{\circ} \mathrm{W}$ longitude were averaged from August through September 2006 (Fig. 3C). The general pattern that $P$. pachyrhizi spores are detected in the western half of the study area roughly a week before being detected in the east suggests a more westerly and perhaps earlier-maturing source of spores than Florida or its surrounding states. The movement of spore deposition from west to east, following the general storm patterns of the United States at this time of year, further validates the findings of this study.
For LDD of spores to be relevant to disease development, spores must be viable. This study did not test for spore viability, and could not as a DNA assay. The detrimental effects of ultraviolet radiation on spore survival have been documented $(18,21)$ and, along with the need for a virulent pathogen, susceptible host, and favorable environmental conditions, using these data alone as a predictor for disease is risky. However, indirect evidence for LDD of viable spores in this study was the relatively long distances between isolated diseased fields in South and North Carolina, western Kentucky, and west-central Indiana in the fall of 2006. These areas did correspond to areas with relatively high and moderate spore deposition 3 to 4 weeks prior to disease development, suggesting LDD of inoculum. A distinction should be made with respect to primary infections and first detection in the field, which may differ greatly.

LDD of viable fungi has been reported by multiple authors $(6,16,21,22,25,27)$. The literature suggests that viable spores are transported considerable distances and deposited in rain. However, there are other confounding factors beyond host susceptibility and environmental conditions that relate to disease development. Independently, Roelfs, while working in Kansas, and Rowell, in Minnesota (A. P. Roelfs, personal communication), found that 1 Puccinia graminis spore in 10 viable spores would cause infection on susceptible wheat but $1 P$. triticina spore in 3 viable spores would cause infection, with other factors being equal. Therefore, the biology of Phakopsora pachyrhizi regarding infection efficiency will need to be taken into account in models predicting disease development beyond simple spore deposition or spore viability.

The primary goal of sequencing qPCR products was to verify the assay results. However, some insight could be made into the population structure of $P$. pachyrhizi in the United States based on the genotypic variation found in the rain samples over the 2-year period of this study, along with that found in a single sentinel plot. A more comprehensive study of genotypes may reveal temporal and geographic patterns that cannot be ascertained by the limited sampling in this study. However, comparing ITS1 sequences from the rain samples and the sentinel plot did show some patterns. The two genotypes found in the sentinel plot, T5 and A5, were the same two predominant genotypes found in the rain samples, suggesting that there is a predominant pathogen population across the United States and, perhaps, in the original source or sources. The results from the sentinel plots, where onethird of the single-leaf samples had both genotypes, suggests that local populations are also genotypically diverse. The dominant genotype in the sentinel plot was also predominant in the rain

\section{Percent found in samples}

\begin{tabular}{|c|c|c|c|c|c|}
\hline A5-MI51 & A $A \begin{array}{lll}A & A & T\end{array}$ & \begin{tabular}{l||llll} 
A & A & $A$ & $A$
\end{tabular} & $-\quad-T A T A T A T A T A$ & 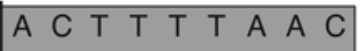 & A5 - $23.0 \%$ \\
\hline A5-AF333489 & A $A$ A $A$ T & A $\mid$ T A A A & - - $T$ A T A T A T A T A & $A C C \quad T \quad T \quad T \quad T A A C$ & \\
\hline A6-SD99 & A A A & $\mathrm{A} \mid \mathrm{T}$ A $\mathrm{A} A$ & 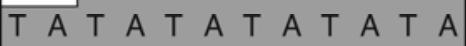 & $A \quad C \quad T \quad T \quad T \quad T A A C$ & $A 6-1.6 \%$ \\
\hline A6-AF333500 & A A A A & $\mathrm{A} \mid \mathrm{T}$ A $\mathrm{A} A$ & 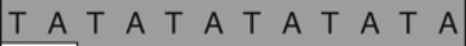 & 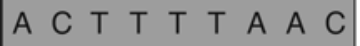 & \\
\hline T5-TN04 & A A A & $\mathrm{T} \mid \mathrm{T}$ A A $\mathrm{A} A$ & $-\quad-\mathrm{T} A \mathrm{~A} A \mathrm{~A} A \mathrm{~T} A \mathrm{~T} A$ & 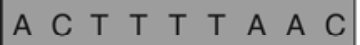 & T5 $-55.7 \%$ \\
\hline T5-AF333499 & A A A $A$ & $\mathrm{~T} \mid \mathrm{T}$ A A A & - $-\mathrm{T}$ A T A T A T A T A & $A \quad C \quad T \quad T \quad T \quad T A A C$ & \\
\hline T6-KS07 & A A A & $\mathrm{T} \mid \mathrm{T} A \mathrm{~A} A \mathrm{~A}$ & 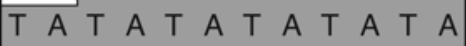 & $A \quad C \quad T \quad T \quad T \quad T A A C$ & T6 $-1.6 \%$ \\
\hline T6-AF333490 & A A A A & $\mathrm{T} \mid \mathrm{T} A \mathrm{~A} A \mathrm{~A}$ & 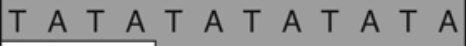 & $A C C \quad T \quad T \quad T A A C$ & \\
\hline T4-GA99 & A A A & $\mathrm{T} \mid \mathrm{T}$ A A $\mathrm{A}$ & $-\cdots$ T A T A T A T A & 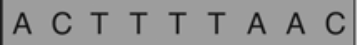 & $\mathrm{T} 4-14.8 \%$ \\
\hline T4-TX03 & A A A $A$ & $\mathrm{~T} \mid \mathrm{T} A \mathrm{~A} A \mathrm{~A}$ & $-\cdots \mathrm{TA}$ - & $A C A \quad T \quad T \quad T A A C$ & \\
\hline $\mathrm{C} 5-\mathrm{MO03}$ & A A A & C & $-\quad T A T A T A T A T A$ & 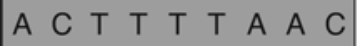 & C5 $-3.3 \%$ \\
\hline C5-NC41 & A $A$ A $A$ T & $\mathrm{C} \| \mathrm{T}$ A A A & - $-\mathrm{T}$ A T A T A T A T A & 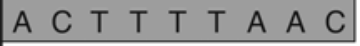 & \\
\hline
\end{tabular}

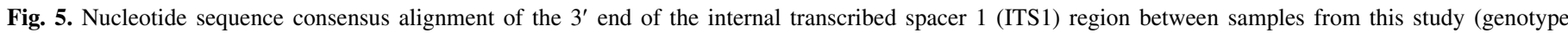

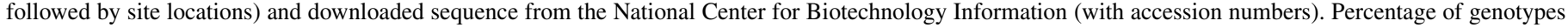

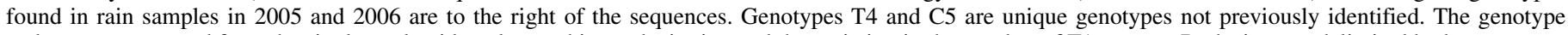
codes were generated from the single nucleotide polymorphism substitution and the variation in the number of TA repeats. Both sites are delimited by boxes. 
samples across the study area over both years and among sequences found in GenBank from isolates collected worldwide. Also, two unique genotypes, T4 and C5, were found that are not found in GenBank. Therefore, genotypic diversity within the population of $P$. pachyrhizi across the United States may be of a predominant genotype but with lower levels of other genotypes mixed in the population. The results of this study do not show a geographic pattern to any particular genotype, noting that sampling for genotypic diversity was not the objective of the study. However, the diversity of genotypes found in this study suggests that either the initial introduction of $P$. pachyrhizi was genotypically diverse, the diversity is a result of multiple introductions of different genotypes, or both.

\section{ACKNOWLEDGMENTS}

Mention of a trademark name or proprietary product does not constitute a guarantee by the United States Department of Agriculture (USDA) or the University of Minnesota. Support for this work was provided by the United Soybean Board and the USDA-Agricultural Research Service. The National Atmospheric Deposition Program (NADP) has more than 240 sponsors, including state agricultural experiment stations; universities; private companies and other nongovernmental organizations; Canadian government agencies; state, local, and tribal government organizations; and federal agencies, including the USDA-Cooperative State Research, Education, and Extension Service (under agreement no. 2007-39138-18202). Any findings or conclusions in this article do not necessarily reflect the views of the USDA or other sponsors. We thank K. Harlin, Central Analytical Laboratory Director; B. Riney of the Illinois State Water Survey-NADP in Champaign, IL; and J. Johnson, K. P. Nguyen, J. Butler, J. Koch, Y. Li, J. Rosnow, S. Wilke, and N. Juergens, of the Cereal Disease Laboratory in St. Paul, MN, for their technical assistance.

\section{LITERATURE}

1. Anikster, Y., Szabo, L. J., Eilam, T., Manisterski, J., Koike, S. T., and Bushnell, W. R. 2004. Morphology, life cycle biology, and DNA sequence analysis of rust on garlic and chives from California. Phytopathology 94:569-577.

2. Barnes, C. W., and Szabo, L. J. 2007. Detection and identification of four common rust pathogens of cereals and grasses using real-time polymerase chain reaction. Phytopathology 97:717-727.

3. Bromfield, K. R. 1980. Soybean rust: some considerations relevant to threat analysis. Prot. Ecol. 2:251-257.

4. Bromfield, K. R. 1984. Soybean Rust. Monogr. No. 11. American Phytopathological Society, St. Paul, MN.

5. Brown, J. K. M., and Hovmøller, M. S. 2002. Aerial dispersal of pathogens on the global and continental scales and its impact on plant disease. Science 297:537-541.

6. Christensen, J. J. 1942. Long distance dissemination of plant pathogens. Pages 78-87 in: Aerobiology. F. R. Moulten, ed. AAAS, Washington, DC.

7. Dossett, S. R., and Bowersox, V. C. 1999. National Trends Network Site Operations Manual. National Atmospheric Deposition Program Office at the Illinois State Water Survey. NADP Manual 1999-01. Champaign, IL.
8. Frederick, R. D., Snyder, C. L., Peterson, G. L., and Bonde, M. R. 2002. Polymerase chain reaction assays for the detection and discrimination of the soybean rust pathogens Phakopsora pachyrhizi and P. meibomiae. Phytopathology 92:217-227.

9. Gregory, P. H. 1973. Microbiology of the Atmosphere, 2nd ed. Wiley, New York.

10. Hirst, J. M. 1959. Spore liberation and dispersal. Pages 529-538 in: Plant Pathology: Problems and Progress, 1908-1958. C. S. Holton, G. W. Fischer, R. W. Fulton, H. Hart, and S. E. A. McCallan, eds. The University of Wisconsin Press, Madison.

11. Isard, S. A., Russo, J. M., and Ariatti, A. 2007. The Integrated Aerobiology Modeling System applied to the spread of soybean rust into the Ohio River valley during September 2006. Aerobiologia 23:271-282.

12. Killgore, E., Heu, R., and Gardner, D. E. 1994. First report of soybean rust in Hawaii. Plant Dis. 78:1216.

13. Krupa, S. Bowersox, V., Claybrooke, R., Barnes, C. W. Szabo, L., Harlin, K., and Kurle, J. 2006. Introduction of Asian soybean rust urediniospores into the Midwestern United States-A case study. Plant Dis. 90:12541259.

14. Levy, C. 2005. Epidemiology and chemical control of soybean rust in southern Africa. Plant Dis. 89:669-674.

15. Melching, J. S., Dowler, W. M., Koogle, D. L., and Royer, M. H. 1989. Effects of duration, frequency, and temperature of leaf wetness periods on soybean rust. Plant Dis. 73:117-112.

16. Mims, S. A., and Mims, F. M. III. 2004. Fungal spores are transported long distances in smoke from biomass fires. Atmos. Environ. 38:651-655.

17. Morel, W., and Yorinori, J. T. 2002. Situacion de la roja de la soja en el Paraguay. Bol de Diulgacion No. 44. Ministerio de Agricultura y Granaderia, Centro Regional de Investigacion Agricola, Capitan Miranda, Paraguay.

18. Nagarajan, S., and Singh, D. V. 1990, Long-distance dispersion of rust pathogens. Annu. Rev. Phytopathol. 28:139-153.

19. Ono, Y., Buritica, P., and Hennen, J. 1992. Delimitation of Phakopsora, Physopella, and Cerotelium and their species on Leguminosae. Mycol. Res. 96:825-850.

20. Pivonia, S., and Yang, X. B. 2004. Assessment of the potential year-round establishment of soybean rust throughout the world. Plant Dis. 88:523529.

21. Prospero, J. M., Blades, E., Mathison, G., and Naidu, R. 2005. Interhemispheric transport of viable fungi and bacteria from Africa to the Caribbean with soil dust. Aerobiologia 21:1-19.

22. Purdy, L. H., Krupa, S. V., and Dean, J. L. 1985. Introduction of sugarcane rust into the Americas and its spread to Florida. Plant Dis. 69:689-693.

23. Roelfs, A. P., Rowell, J. B., and Romig, R. W. 1970. Sampler for monitoring cereal rust uredospores in rain. Phytopathology 60:187-188.

24. Rowell, J. B. 1984. Controlled infection by Puccinia graminis f. sp. tritici under artificial conditions. Pages 291-332 in: The Cereal Rusts, vol. 1. A. P. Roelfs and W. R. Bushnell, eds. Academic Press, New York.

25. Rowell, J. B., and Romig, R. W. 1966. Detection of urediospores of wheat rusts in spring rains. Phytopathology 56:807-811.

26. Schneider, R. W., Hollier, C. A., Whitam, H. K., Palm, M. E., McKemy, J. M., Hernandez, J. R., Levy, L., and DeVries-Paterson, R. 2005. First report of soybean rust caused by Phakopsora pachyrhizi in the continental United States. Plant Dis. 89:774.

27. Stakman, E. C. 1942. The field of extramural aerobiology. Pages 1-7 in: Aerobiology. F. R. Moulten, ed. AAAS, Washington, DC.

28. Stakman, E. C., and Christensen, C. M. 1946. Aerobiology in relation to plant disease. Bot. Rev. 12:205-253. 